\title{
The past, present and future of dragonfly research in Indonesia
}

\author{
Pungki Lupiyaningdyah*
}

Zoology Division - Museum Zoologicum Bogoriense, Research Center for Biology, Indonesian Institute of Sciences (LIPI), Gedung Widyasatwaloka, Jl. Jakarta Bogor Km. 46, Cibinong, 16911, Jawa Barat, Indonesia

\begin{abstract}
Up to present, Indonesia has 900 described species of dragonflies with around $70 \%$ are endemic; among them, the most diverse is in Papua. This data is collected based on 356 publications from scientific journals, bulletins, magazines, books, theses, and proceedings from 1773 to 2019 . There is still a lack of information about what is the most and least popular topics and where is the most explored regions in Indonesia for Odonata research. I categorized the topics into biodiversity, taxonomy and systematics, biogeography, conservation, ecology, education, ethnozoology, history, and molecular. The result shows that the most popular topic is biodiversity by 139 publications and the least are history and molecular by only one publication. Most popular group to be observed is dragonflies in general (both suborders) by 200 publications and the least observed is Anisoptera by only 71 publications. Java is the most explored island for about 160 publications in 250 years.
\end{abstract}

\section{Introduction}

Dragonflies and damselflies have been an interesting object to be studied for years, from the beginning of Linnaeus era until present. In Indonesia, this particular order had been reported from 1773 by European military officer who interested in dragonflies while he was on duty in Dutch Indies archipelago [1].

Starting from late 1700 to 1950 , the exploration of Odonata in Indonesia continued to grow. These were in the colonial era, where a military officer who also a naturalist and biologist collected many dragonflies and damselflies to bring to their country natural history museum or for their private collection and they identified the specimens and published their findings in journals, magazines, and bulletins [1-9]. In the era of 1950 to 1990 , the researches on Odonata are not as many or massive as before 1950s. Researchers were going to another country in Southeast Asia to explore more.

The interesting moment for Indonesian people especially the young generation to be interested in Odonata group occurred in 2010. This was the era of social media, Facebook boomed and people almost every day being online to read news feeds and new pictures that were posted. The young generations or millennial generation were also in the euphoria of photography, especially wildlife animals and plants, landscape and nature in general. One of the wildlife animals that is easy to capture by camera and seen in our garden or public park is Odonata. Therefore, many people posted dragonflies and damselflies pictures on * Corresponding author: pungkilupi@gmail.com
Facebook and asked about the name of the species. This leads to the undergraduate started to use Odonata as their subject for their final thesis. Most of the research locations were in Java.

At present, dragonfly biodiversity in the world is 6322 species [10], whereas Indonesia has around 900 described species of dragonflies, which means Indonesia has around $14 \%$ of world's biodiversity. The most diverse island is Papua with 375 species, Kalimantan 291 species, Sumatra 257 species, Java 183 species, Maluku 149 species, Sulawesi 146 species, Lesser Sunda Islands 96 species, and the least is Bali with only 58 species [11].

Nevertheless, we never knew the research topics that have been carried out from hundred years ago until now in Indonesia are still relevant to the nature condition at present or later in the future. Based on enormous publications on Odonata research in Indonesia, thus lead me to questions: what research topics were most studied by researchers in the past? Which island that is most observed and explored for hundred years? What group of suborders that is most observed over the years? What research studies that will give more impact to human and conservation? So, we could reduce and elude redundancy of similar observations.

\section{Material and Methods}

I gathered 356 references about research on Odonata in Indonesia from 1773 to 2019 . I collected and arranged the references from Museum Zoologicum Bogoriense 
Library, Biodiversity Heritage Library (www.biodiversitylibrary.org), Internet Archive (www.archive.org), Google Scholar, open access journals from Indonesian universities and portals, www. researchgate.net, medusa.jcu.edu.au, Naturalis Biodiversity Center repository (repository.naturalis.nl), and some copies from colleagues and odonatologists.

The references are categorized into research topic, group of study, island, author nationality and group of year (per 20 years). Research topics are divided into nine subjects (Table 1). Group of study based on the suborders Anisoptera, Zygoptera, or both. The island are divided into 14 regions, as follows: Java, Sumatra, Kalimantan, Sulawesi, Maluku, Lesser Sunda Island (LSI), Papua, Bali, Lombok, Papua-Maluku-Sulawesi, Sumatra-Jawa, Sumatra-Jawa-Kalimantan-Sulawesi, Sumatra-Jawa-Kalimantan, Sumba, and Timor. The author nationality is divided into 18 countries, with most of the countries were came from Europe. The year of publication is grouped with interval of 20 years from 1773 to 2019. All data are depicted into charts.

Table 1. Categories of Odonata references

\begin{tabular}{|l|l|}
\hline Categories & Note \\
\hline Topics & Inventory, diversity, report, collection \\
\hline Biodiversity: & $\begin{array}{l}\text { Taxonomy \& } \\
\text { Systematics: } \\
\text { morphology, records }\end{array}$ \\
\hline $\begin{array}{l}\text { Biogeography } \\
\text { Mast, 2010): }\end{array}$ & $\begin{array}{l}\text { Spatial and non-spatial distribution of groups or } \\
\text { species }\end{array}$ \\
\hline Conservation: & Biodiversity loss, critical species \\
\hline Ecology: & $\begin{array}{l}\text { Distribution, assessment, behaviour, composition, } \\
\text { habitat, ecosystem, bioindicator }\end{array}$ \\
\hline Education: & $\begin{array}{l}\text { Odonata as a model for teaching environmental } \\
\text { topic }\end{array}$ \\
\hline Ethnozoology: & $\begin{array}{l}\text { Odonata in the perspective of local wisdom and } \\
\text { cultural knowledge }\end{array}$ \\
\hline Molecular & DNA barcoding, sequences, genetics \\
\hline History & Odonata drawings from around 1800s \\
\hline
\end{tabular}

\section{Results and Discussion}

\subsection{Research topics}

Odonata research in Indonesia for nearly 250 years (1773-2019) are dominated with the topics of biodiversity (140 publications) and taxonomy \& systematics (142 publications). The least published research topics are history and molecular with only one publication (Fig. 1). These results could be because of the geography of Indonesia that is unique as an archipelago, thus researchers always want to explore to remote site or island to have new findings. Two hundred fifty years still not enough to explore biodiversity in a large country like Indonesia. Other subjects like ecology, conservation, education, ethnozoology are not studied deeper.

\footnotetext{
*Corresponding author: pungkilupi@gmail.com
}

Beside all Indonesia has been observed for more than two hundred years, Java (79 publications) and Papua (46 publications) has been the islands of interest to study. Java was selected as area for study are in recent years by the undergraduate students, meanwhile Papua has been a place of interest since before 2000 and become popular in 2010 to present by the foreign researchers, especially from Netherlands and Australia.

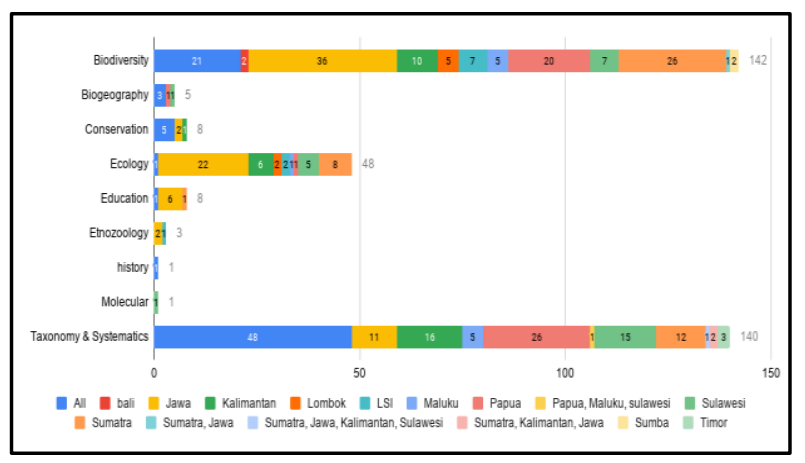

Fig 1. Comparison of research subjects on Odonata in Indonesia islands in the past 250 years (1773-2019).

Moreover, if we compare from the period of the year, the last six years (2013-2019) the most popular research topic is Biodiversity in 11 islands, follows by Ecology and Taxonomy and Systematics each in seven islands. In the past, the proportion of both topics Biodiversity and Taxonomy and Systematics are almost equal (17732012) (Fig 2). The molecular topic just appeared in 2016 and the publication is about DNA barcoding of Libellulidae. The topic is very basic molecular, not the advanced one. So, the elaboration of the molecular subject on Odonata of Indonesia for the future is still wide open.

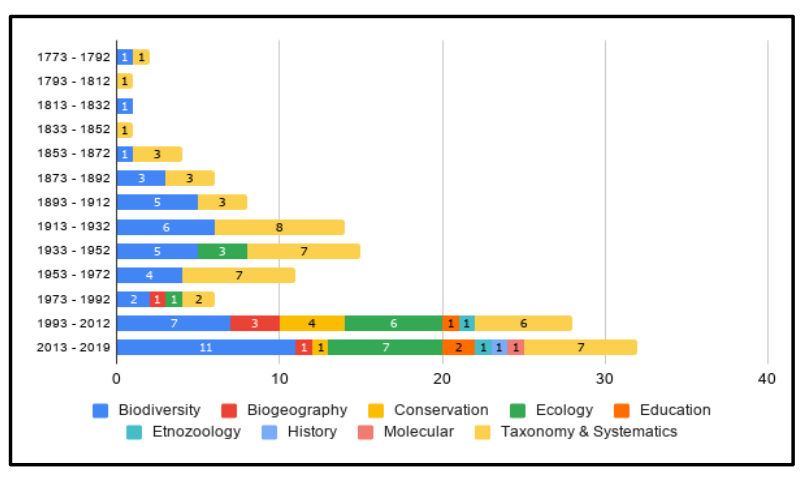

Fig 2. Comparison of research topics on Odonata from 1773 to 2019 .

\subsection{Study Group}

Suborder of Odonata that is most favourite to study all time are both Anisoptera and Zygoptera, because most of the publications discuss the biodiversity of Odonata in an area, so the authors must discuss both dragonflies and damselflies. Except if the authors are interested in a particular family such as study about the behaviour or revise some group then the publication will focus only on one suborder, either Anisoptera or Zygotera. The last 
six years (2013-2019) is the peak of both groups being studied (112 publications). Most of the publications were written by Indonesian undergraduate students who discuss the diversity of Odonata in a particular area, such as mountains, conservation areas and their hometown (Fig. 3).

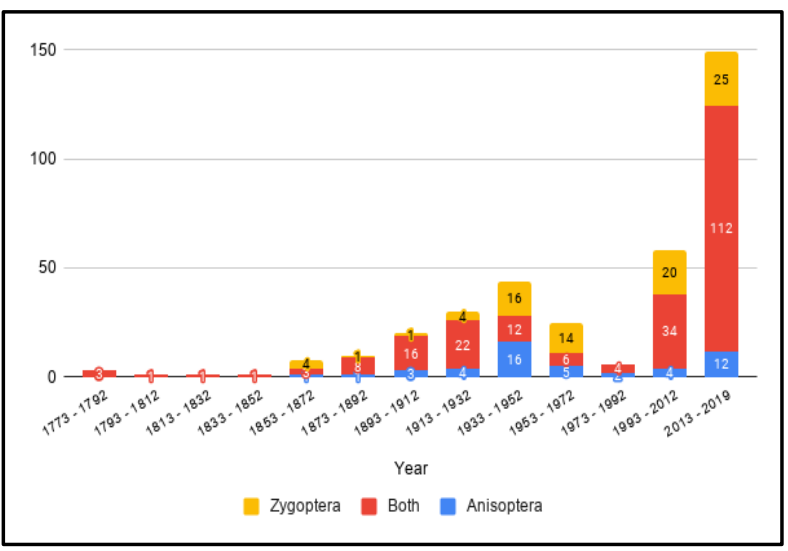

Fig 3. Comparison of subject groups (Suborders) that were published in the past 250 years.

\subsection{Research Locations}

Indonesia in general, despite the location and the time is always interesting to be observed by the researchers to know more about Odonata in its habitat. Second place is Java, although this island has experienced a major transformation from dense lowland rainforest to an industrial city and urban settlement, the researcher always could find something new from this island, such as new record or species that have been a long time not reported after hundred years, it still exists in a very secluded area usually in mountain area (Fig. 4).

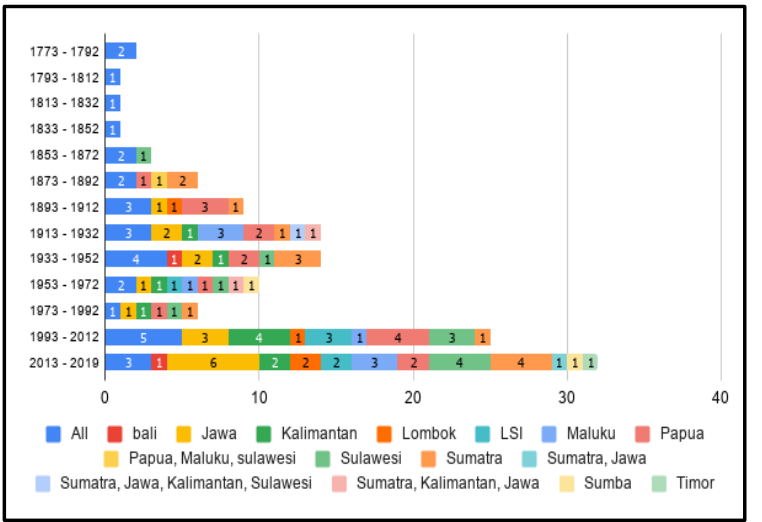

Fig 4. Comparison of research locations to study Odonata in Indonesia based on islands from 1773 to 2019.

\subsection{Country of origin of the authors}

The proportion of authors of Odonata of Indonesia publications is dominated by Indonesia in this past six years (2013-2019). As aforementioned, undergraduate students became interested in studying Odonata because of the era of Facebook and this is a good example of the impact of social media to science. But, before 2013, the *Corresponding author: pungkilupi@gmail.com authors who dominated the publication on Indonesian Odonata are from the Netherlands. This perhaps related to the long history between Netherlands and Indonesia in terms of the colonial period and most of their collections in Naturalis are came from Indonesia and the "father" of Odonata of Indonesia was M.A Lieftinck that had published hundreds of manuscripts on Indonesian Odonata. Not to mention that he was the Head of Museum Zoologicum Bogoriense around 1940-1950s. The authors from Belgium also contributed many publications on Odonata of Indonesia, since they had some expedition to Papua and Dutch Indies area (now Indonesia) (Fig. 5).

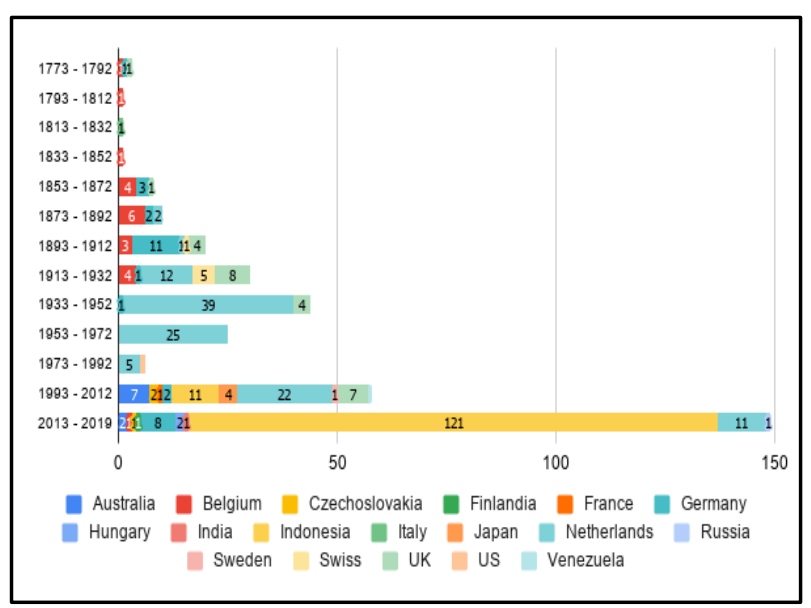

Fig 5. Comparison of the origin of the author who published about Indonesian Odonata every 20 years.

\subsection{Future studies on dragonflies in Indonesia}

Finally, the trends of Odonata researches in Indonesia from time to time remains the same for hundred years that are more to explore and uncover the biodiversity of dragonflies. Researchers and students should elaborate more topics in the future to uncover the potency and importance of Odonata in nature and for human benefits. The subjects that could be explored more in the future are molecular like next-generation sequencing, the microbiome in Odonata's gut, the taxonomy of Odonata larvae and mapping the distribution of dragonflies in Indonesia that could be used as conservation action and management consideration.

\section{Conclusion}

Researches on Odonata show the same pattern over the years which biodiversity and taxonomy and systematics are still the most popular subjects among the students and researchers to study Odonata in Indonesia. The least popular subject to study are history and molecular. In the future, a molecular study on Odonata should be the main goal, because the technology era has been moved to DNA barcoding, genomics study using NGS technique, and molecular phylogenetic analysis. One goal of this review is to inspire more research groups, to 
expand their objectives to include molecular studies, especially in the islands that are still lack of exploration.

I would like to thank to MZB Library, BHL, archive.org, for the free access to download the literatures. All of my colleagues that have been sending me the literatures. Thank you to International Symposium on Indonesian Fauna 2019 scientific committee who accepted and selected my manuscript to be submitted to the International Proceeding.

\section{REFERENCES}

1. D. Drury, Illustrations of natural History Vol. II (Printed by B. White, London, 1773)

2. J.C. Fabricius, Systema entomologiae, sistens insectorum classes, ordines, genera, species, adiectis synonymis, locis, descriptionibus, observationibus, Odonata (Libraria Kortii, Flensburgi et Lipsiae, 1775)

3. E. Sélys-Longchamps. Mittheilungen Koeniglichen zoologischen Museum zu Dresden 3, 289323(1878)

4. H. W. van der Weele, Nova Guinea Zoology 9 (1), 19-25 (1909)

5. R. Martin, Collections zoologiques du Baron Edmund de Sélys-Longchamps, Catalogue Systématique et Descriptif, 20, 157-223 (1909)

6. F. Ris, Collections Zoologiques Baron Edm Selys Longchamps 16 (2) 1043-1278 (1919)

7. M.A. Lieftinck, Treubia 16 (1), 1-82 (1937)

8. M.A. Lieftinck, Treubia 17 (4), 337-390 (1940)

9. M.A. Lieftinck, Treubia 20, 631-645 (1950)

10. M. Schorr, D. Paulson. http://www. pugetsound. edu/academics/academic-resources/slatermuseum/biodiversity-resouces/dragon flies/worldodonata-list2/. (Accessed July 14, 2019).

11. P. Lupiyaningdyah, N. Kamaludin, S. Diniarsih, F. Irawan, Daftar Capung Indonesia. (Unpublished raw data 2019)

\footnotetext{
*Corresponding author: pungkilupi@gmail.com
} 